\title{
ЯКІСТЬ ЖИТТЯ ПАЦІЄНТІВ З ХРОНІЧНИМ ПАНКРЕАТИТОМ І СУПУТНІМ АСКАРИДОЗОМ
}

\author{
СЮ. В. Дроняк, Л. С. Бабінець
}

ДВНЗ «Тернопільський державний медичний університетімені І. Я. Горбачевського МОЗ України»

РЕЗЮМЕ. У статті наведені результати проведеного порівняльного аналізу якості життя пацієнтів 3 хронічним панкреатитом та супутнім аскаридозом. При хронічному панкреатиті із супутнім аскаридозом у хворих було констатовано достовірно нижчий рівень показників якості життя за всіма шкалами як неспецифічного опитувальника SF-36, так і специфічного для патологі шлунково-кишкового тракту опитувальника GSRS. Це засвідчило об'єктивну обтяжуючу роль супутнього аскаридозу на перебіг хронічного панкреатиту [3, 4].

КЛЮЧОВІ СЛОВА: хронічний панкреатит, аскаридоз, якість життя, опитувальники SF- 36 та GSRS.

Вступ. Останніми роками вивчення якості життя у всьому світі $\epsilon$ однією з актуальних проблем у медицині. Відбувається відродження підходу до оцінки хворого, а не хвороби, у вигляді концепці дослідження якості життя. Поняття «якість життя» покладено в основу ново парадигми розуміння хвороби та визначення ефективності методів лікування. У сучасній медицині поширився термін «якість життя, пов'язана зі здоров'ям» Це той термін, який оцінює не стільки хворобу, скільки хворого [1]. Відповідно до ново концепці клінічно медицини якість життя (ЯЖ) хворого є або головною, або додатковою, або єдиною метою лікування. Оцінка ЯЖ особливо важлива при хронічних захворюваннях, що вимагають тривало терапі [2]. Все більша увага приділяється вивченню поєднання гастроентерологічних захворювань із гельмінтозами [6]. Високе медикосоціальне значення хронічного панкреатиту (XП), як і аскаридозу (А), визначається х значним внеском у патологію людей соціально активного віку, великими витратами на діагностику і лікування, зниженням ЯЖ і працездатності. Саме тому вважали актуальним вивчити цю проблему $[7,8]$.

Мета дослідження: порівняти якість життя пацієнтів з хронічним панкреатитом та таким у поєднанні з аскаридозом.

Матеріал і методи дослідження. Обстежено 53 пацієнти з ХП. Хворі були поділені на дві групи: до І увійшли 33 пацієнти з ХП у поєднанні з А, до II 20 осіб із ХП.

Для оцінки ЯЖ використали стандартизовані міжнародні загальний та специфічний опитувальники. Загальні опитувальники застосовуються при будь-якому патологічному стані, дозволяють порівнювати ЯЖ при різних захворюваннях, але не оцінювати специфічні для конкретно патологі аспекти. Специфічні опитувальники малочутливі в оцінці впливу супутньо патологі . Тому для достовірності результатів ми використовували одночасно як специфічний, такі неспецифічний опитувальники [2].

ЯЖ обстежуваних пацієнтів визначали за допомогою загального опитувальника Medical Outcomes
Stady 36-Itm (Mos SF-36), в якому 36 пунктів згруповані у 8 шкал. Показники кожно шкали варіюють між 0 і 100 балами, де 100 балів - повне здоров'я. Всі шкали формують два показники: душевне та фізичне благополуччя. Кількісно оцінювалися такі показники:

1) фізичне функціонування, що оцінює, наскільки фізичний стан обмежує виконання фізичних навантажень (ходьба, підйом сходами і т.п.);

2) рольове функціонування, обумовлене фізичним станом - вплив фізичного стану на повсякденну діяльність (роботу, повсяқденні обов'язки);

3) інтенсивність болю;

4) загальний стан здоров'я - оцінка хворим свого стану здоров'я в даний момент і перспектив лікування;

5) життєва активність;

6) соціальне функціонування;

7) рольове функціонування, обумовлене емоційним станом; шкала передбачає можливість оцінки, наскільки емоційний стан заважає виконанню роботи або іншо повсяқденно діяльності;

8) психічне здоров'я, яке характеризує настрій, наявність депресі, тривоги, загальний показник позитивних емоцій.

Фізичний компонент здоров'я відображають шкали з 1 по 4, а психологічний компонент - 35 по 8.

Для оцінки вираженості гастроентерологічно симптоматики і ЯЖ використовувалася російська версія спеціального опитувальника Gastrointestinal Symptom Rating Scale (GSRS), що містить 15 питань, згрупованих у 5 шкал: абдомінальний біль, рефлюкс-синдром, запор, діарея, диспепсія. Показники шкал коливаються від 1 до 7, більш високі значення відповідають більш вираженим симптомам та нижчій ЯЖ [5].

Обробка результатів виконана у відділі системних статистичних досліджень ДВНЗ «Тернопільський державний медичний університет імені І. Я. Горбачевського МОЗ Укра ни» у програмному пакеті Statsoft Statistica. 
Оеляди літератури, ориаінальні дослідження, поеляд на проблему

Результати й обговорення. Оцінка результатів проведеного дослідження показала, що ЯЖ пацієнтів із ХП+А в порівнянні з ХП була статистично значуще нижчою за шкалами, які оцінювали психологічний і фізичний компонент здоров'я $(p<0,05)$. За даними таблиці 1 , наявність супутнього А вірогідно погіршувала ЯЖ хворих на ХП за всіма шкалами, що відображають фізичний стан пацієнта, а саме - фізичну активність, роль фізичних проблем в обмеженні життєдіяльності, інтенсивність болю, загальний стан здоров'я, життєву активність. Серед хворих на ХП+А низькі показники відзначалися і за шкалами психоло- гічного здоров'я, що вказує на те, що повсякденна діяльність хворого не обмежується клінічними проявами аскаридозу, а й супроводжується негативним емоційним забарвленням, різким занепадом сил та енергі, відсутністю спонукань і достатнього фізичного потенціалу для адекватного виконання повсяқденно роботи, що пов'язано з наявністю двох одночасно існуючих захворювань. ЯЖ при ХП+А знижена як через частоту та виразність симптомів, так і через негативне емоційне забарвлення, яке вони викликають, що підтверджується низьким балом за шкалами (табл. 1).

Таблиця 1. Порівняльний аналіз якості життя за шкалами опитувальника SF-36 у балах

\begin{tabular}{|l|c|c|}
\hline \multicolumn{1}{|c|}{ Шкала опитувальника SF-36 } & \multicolumn{2}{|c|}{ Група порівняння } \\
\cline { 2 - 3 } & $\begin{array}{c}\text { ХП, } \\
\mathrm{n}=20\end{array}$ & $\begin{array}{c}\text { ХП+A, } \\
\mathrm{n}=33\end{array}$ \\
\hline Фізичне функціонування & $71,6 \pm 0,9$ & $52,8 \pm 0,9^{*}$ \\
\hline Рольове фізичне функціонування & $44,1 \pm 0,9$ & $26,6 \pm 0,7^{*}$ \\
\hline Інтенсивність болю & $70,0 \pm 0,8$ & $43,3 \pm 1,0^{*}$ \\
\hline Загальне здоров'я & $46,4 \pm 0,7$ & $34,4 \pm 0,7^{*}$ \\
\hline Життєздатність & $47,4 \pm 0,7$ & $25,5 \pm 0,7^{*}$ \\
\hline Соціальне функціонування & $73,1 \pm 0,9$ & $45,2 \pm 1,0^{*}$ \\
\hline Рольове функціонування, зумовлене емоційним здоров'ям & $63,5 \pm 0,8$ & $33,2 \pm 0,7^{*}$ \\
\hline Психологічне здоров'я & $54,3 \pm 0,7$ & $44,0 \pm 0,8^{*}$ \\
\hline
\end{tabular}

Примітка: * - вірогідність різниці показників в групі ХП+А стосовно таких групи ХП $(p<0,05)$.

Аналізуючи дані тестування хворих з ХП+А за допомогою спеціалізованого гастроентерологічного опитувальника GSRS було встановлено, що провідне місце в клініці захворювання займають больовий, рефлюксний та диспепсичні синдроми (p>0,05). Ці синдроми слід розглядати як основний фактор, що знижує ЯЖ у пацієнтів з ХП+А.
Підвищення показників за шкалою діаре та запору в групі ХП+А обстежених хворих було менш значним. Сумарний бал за шкалою сумарного визначення (середнє арифметичне значення показників усіх шкал) опитувальника GSRS було $(3,6 \pm 0,2)$ і $(2,5 \pm 0,1)$ відповідно у пацієнтів з ХП+А та ХП (рис. 1).

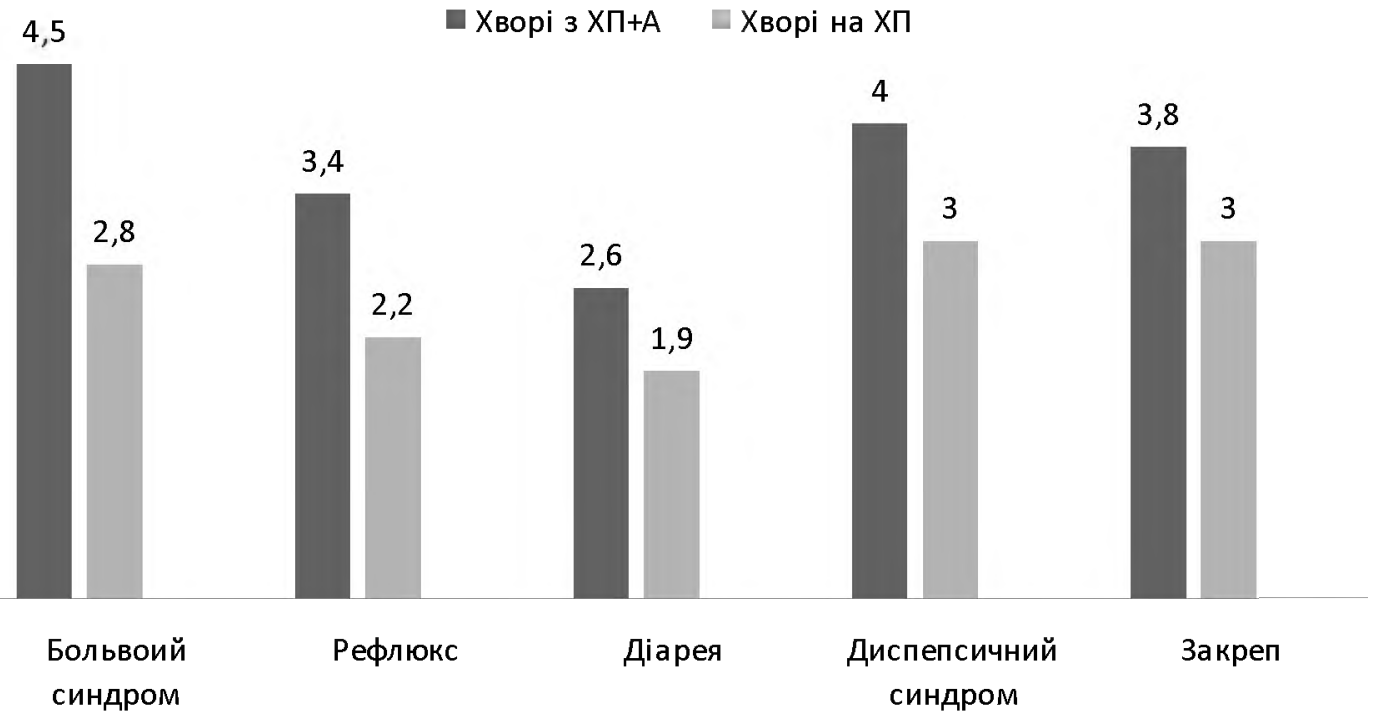

Рис. 1. Показники основних симптомів у хворих з ХП та ХП+А. 


\title{
Оеляди літератури, оригінальні дослідження, поеляд на проблему
}

Висновки. У хворих на хронічний панкреатит із супутнім аскаридозом було констатовано достовірно нижчий рівень показників якості життя за всіма шкалами як неспецифічного опитувальника SF-36, так і специфічного для патологі шлунковокишкового тракту опитувальника GSRS (сумарний бал $(3,67 \pm 0,04)$ і $(2,57 \pm 0,03)$ відповідно) стосовно таких у групі хворих на ХП. Це засвідчило об'єктивну обтяжуючу роль супутнього аскаридозу на перебіг хронічного панкреатиту.

у перспективі подальших розробок $\epsilon$ проведення моніторингу стану здоров'я та якості життя пацієнта після запропонованого лікування в ранні та віддалені терміни.

\section{ЛІТЕРАТУРА}

1. Новик А. А. Руководство по исследованию качества жизни в медицине / А. А. Новик, Т. И. Ионова - СПб. : Издательский Дом«Нева», М. : «ОЛМА-ПРЕСС» Звездный мир, 2002. - $320 \mathrm{c}$.

2. Ягенський А. В. Оцінка якості життя в сучасній медичній практиці/ А. В. Ягенський, І.М.Січкарук // Внутрішня медицина. - 2007. - Т. 3, № 3. - С. 57-62.

3. Бабінець Л. С. Аскаридоз і хронічний панкреатит: спільні етіопатогенетичні аспекти, оптимізація лікування в практиці сімейного лікаря / Л. С. Бабінець, Ю.В.Дроняк // Сімейна медицина. - 2014. - № 2. - С. 101-104.

4. Ефективність етіологічно корекці супутнього аскаридозу в комплексному лікуванні хронічного панкреатиту [Текст] / Л. С. Бабінець [та ін.] // Лікарська справа : Науково-практичний журнал. - 2014. - № 11. C. $116-118$.

5. Супутнє хронічне обструктивне захворювання легень як предиктор ускладнення клінічного перебігу та зниження якості життя при хронічному панкреатиті / Л. С. Бабінець, О. С. Квасніцька, О.І.Криськів [та ін.] // Буков. мед. вісн. - 2011. - № 15, № 3. - С. 153-156.

6. Pezzilli R. The Quality of Life in Chronic Pancreatitis: The Clinical Point of View / R. Pezzilli, L. Fantini, L. Calculli // J Pancreas. - 2006. - 7(1 Suppl.). - P. 113-116.

7. Symptoms and quality of life in chronic pancreatitis assessed by structured interview and the EORTC QLQ-C30 and QLQ-PAN26 / D. Fitzsimmons, S. Kahl, Butturini G, van Wyk M [et al.] // Am. J. Gastroenterol. - 2005. - V. 100. P. 918-926.

8. Nair R. J. Chronic Pancreatitis / R. J. Nair, L. Lawler, M. R. Miller // Am. Fam. Physician. - 2007. - Vol. 76, № 11. P.1679-1688.

\section{QUALITY OF LIFE OF PATIENTS WITH CHRONIC PANCREATITIS AND CONCOMITANT ASCARIASIS}

\author{
(CYu. V. Dronyak, L. S. Babinets \\ SHEI «Ternopil State Medical University by I. Ya. Horbachevsky of MPH of Ukraine»
}

SUMMARY. The article presents the results of a comparative analysis of the quality of life of patients with chronic pancreatitis and concomitant chronic pancreatitis with ascariasis. When chronic pancreatitis with concomitant ascariasis patients was ascertained significantly lower quality of life for all scales as non-specific questionnaire SF- 36 and for specific pathology of the gastrointestinal tract questionnaire GSRS. It showed objective aggravating role of the associated ascariasis for course of the chronic pancreatitis.

KEY WORDS: chronic pancreatitis, ascariasis, quality of life, quentionnaire SF- 36 and GSRS.

Отримано 20.03.2015 